DOI: https://doi.org/10.3126/njdrs.v15i0.31602

\title{
Motivational Factors for Women Employment in Vyas Municipality of Tanahu District, Nepal
}

\author{
Ranju Rimal* and Rajan Binayek Pasa* * \\ *Field Reporter, National Society for Earthquake Technology (NEST), Bhaisepati, Lalitpur \\ **Faculty, Central Department of Rural Development, Tribhuvan University \\ Email for correspondence: ranju.rimal11@gmail.com and rajan.pasa@cdrd.tu.edu.np
}

\begin{abstract}
This study explains motivational/de-motivational factors for women employment from rural development standpoint. In doing so, quantitative approach and case study research design have been applied. The numeric data are collected from 72 respondents whereas narrative information are generated from five participants selected form five government and five non-government institutions of Vyas Municipality of Tanahu District. In this stance, anonymous self administered questionnaires and key informant interview techniques are applied. The result shows that motivational factors (i.e. salary, bonus, security, safety promotion) are encouraging women to perform their duty/ responsibility effectively and efficiently with honorable way. They are not only supporting to their family livelihood but also playing gender role (social, economic \& political roles) in community and society. However, some of the respondents are also experiencing less paid salary, sexual harassment, physical difficulties at the time of menstruation and not sufficient maternity leave (de-motivational factors). De-motivated women are failed to join in higher education and unable to perform gender role for rural development. Thus, better to address de-motivational factors by the local development stakeholders including aged persons supporting deeply rooted patriarchal systems of Hindu culture for motivating women for employment.
\end{abstract}

Key words: Women employment, motivational factor, de-motivational factor, gender role, rural development

\section{Introduction}

The term motivation is derived from the world motive. Motivation is willingness and energy to devote for a certain task continually, until the desire result is achieved. It is a psychological phenomenon that encourage individual to perform their activities more effectively and efficiently that is must for achieving desired organizational goals. However, motivational science is not only limited to the psychological factors, apart from the psychology the factors like education, health, business also affects the motivational level of human beings (Higgins \& Kruglanski, 2000). Likewise, the forces such as biological, social, emotional and cognitive derive the motivational factors. Basically, motivational factors are categorized into two parts i.e. intrinsic factors and extrinsic factors.

The intrinsic or internal factors are mostly related to the human behavior and psychology. It comes from an individual himself/herself. The literature says that when somebody work without expecting any extrinsic rewards and enjoy their work or learn and explore innovative ideas then intrinsic motivation occurs (Hiam, 2003 as cited in Chapagai, 2017). More specifically, challenge, 
curiosity, recognition, competition, co-operation, control etc are some of the examples of intrinsic motivational factors (Fischer, Malycha \& Schafman, 2019). Accordingly, extrinsic or external factors are very essential to motivate the employees. The factors that involved to make the people to work in the expects of something, very often related to the rewards are the extrinsic factors. The extrinsic factors can be financial rewards, pressure from the colleague, promotion, threats of punishment (Hiam, 2003 as cited in Chapagai, 2017).

In this background, in general, motivation is an essential factor for women employment that is inevitable for rural development. Rural development is a process, phenomenon and discipline that encompass agriculture development and allied activities, village industries and crafts as well as socioeconomic infrastructures in rural areas (Singh, 2009). Rural development process seeks to alleviate poverty, mass utilization of resources, commercialization of agriculture, food security, creating opportunities, infrastructural development of rural community and modernization of the society (Chaudhary \& Pasa, 2015). However, in particular, women employment can empowers women and encourage them to involve in development process. The approaches like women in development (WID), women and development (WAD) and gender and development (GAD) are evolved in this regard. WAD approach was developed by neo-Marxist feminist. It is an important bridge between WID and GAD. This approach comes from the perspective that is essential for improving women's positions through their reproductive and productive capacities. Globally, the Convention on the Elimination of All Forms of Discrimination against Women (CEDAW) was adopted in 1979 by the UN General Assembly. Similarly, the Beijing Platform for Action (BFA) was the resulting document of the Fourth World Conference on Women in Beijing, China in 1995. It was also adopted in consensus by the UN member countries. The BPFA represents the international community's commitment towards the promotion of women's welfare and aims at accelerating. The conventions have been ratified by 185 member countries of UN including Nepal. However, in practice, gender development index for developed, middle income and least developing countries are Norway (0.991), China(0.959), India (0.841) and Nepal (0.925) respectively (UN, 2017). UN Report (2017) says that there are currently 1.4 billion people living in extreme poverty in the world, and two thirds of these people are women. In the Global South, 80 percent of employment opportunities for women are in the informal sector. Of the 110 million children who do not have access to education, two thirds of them are girls.

Owing to research in Nepalese context, the share of working age population $(15+$ years $)$ to the total population is 71.5 percent. Among them 55.6 percent are females. The overall unemployment rate in the country is 11.4 percent and unemployment rate for the females is 13.1 percent $(2.8 \%$ points higher compared to males) (CBS, 2019). The fact indicates that there is a huge disparity in the labor market indicators is seen between females and males. The female employment-to-population (EPR) is 22.9 percent, which is 25.4 percentage points lower than the male EPR. The female labor force participation rate (LFPR) is 26.3 percent compared to the male (53.8 percent). Even, 7 percent of woman aged 1549 has experienced sexual violence in public and work place (NDHS, 2016). The question of women's equality and security in the workplace is at the nexus of many social issues and social conceptualizations of women: women as workers, as mothers, as victims of violence against women (VAW), as a victim of sexual violence, Many women activists and organization are although playing crucial role in elimination of any forms of violence and woman, it is deeply rooted specially in patriarchal society. 
Finally, in one hand, in certain sectors, women are taken as cheap labor and are paid fewer wages than their male counterparts. Females workplace, too, is not often adequately designed where they could feel at ease during work and break timings. Such unfriendly and oppressive behavior of employers is not a peculiarity of our society; rather it is a world-wide problem, and an offspring of the capitalistic approach, in which the real goal of any entrepreneur is profit maximization, and not human welfare (Averett, Laura \& Hoffman, 2018). In another hand, Zimmerman and Schunk (2012) emphasizes that motivation is related to psychology and the forces that motivate people are different from one person to another. The same factor cannot motivate all the people and it is always essential to find the effective factor for a single people e.g. reward may motivate one person, but another person may be seeking for recognition. Here is why, this study explains motivational and de-motivational factors for women employment in particular context of Vyas municipality located in Tanahu District.

\section{Objectives}

- To examine social and demographic characteristics of the respondents.

- To assess motivational factors for women employment.

- To explain de-motivational factors for women employment.

\section{Materials and Methods}

This study applied quantitative dominant case study research methodology. Case as "a bounded system" and inquire into it "as an object rather than a process". It is a specific or a complex functioning thing like; boundary and working parts and purposive social interactions (Stake, 1995, p. 2 as cited in Yazan, 2015; Yin, 2013). Therefore, in this study purposively selected 10 institutions (i.e. five governments \& five non-governments) were regarded as multiple cases of the study. The required data are collected from 72 respondents (unit of analysis [Table 1]) selected by using multistage sampling method that is generated with 95 percent confidence level and 5 percent marginal error (Krejcie \& Morgan, 1970). Likewise, necessary narrative information are also generated by five participants selected purposively. In this stance, self administered questionnaires and key informant interview techniques are applied.

\section{Table 1. Sampling and Population}

\begin{tabular}{clcl}
\hline Stages & Categories & Number & Remarks \\
$\mathbf{1}$ & $\begin{array}{l}\text { Total male \& female employees of five government } \\
\text { \& five non-government institutions }\end{array}$ & 229 & Theoretical population \\
$\mathbf{2}$ & $\begin{array}{l}\text { Total female employees of five government and } \\
\text { five non-government institutions }\end{array}$ & 105 & Sample population \\
$\mathbf{3}$ & Randomly selected female employees & 72 & Sample number \\
\hline
\end{tabular}

\section{Vyas Municipality At a Glance}

Vyas Municipality (VM) is located in Tanahun District of Gandaki province. The municipality is located at $27^{\circ} 58^{\prime} 35^{\prime \prime}$ north and $84^{\circ} 16^{\prime} 5^{\prime \prime}$ east has covered 86 square kilometer total area. Total population of the municipality is 70,335 with 820 per kilometer density (VM, 2018). Out of total, 83 percent populations are literate and remaining 17 percent are illiterate. The municipality has good networking of road accessibility, electrification and marketing facilities as well as modern technology and communication. 
The municipality is also rich from natural and socio-cultural view points. Due to versatile beauty and cultural diversity offered by the nature, this municipality bears plenty of potentiality and opportunity for Tourism development. Chhabdi Barah Darshan, Bhanu Ghansi Memorial Park Visit, Manhaunkot Trekking, Shiva Panchayan and Vyas Cavevisit, Madi River Rafting etc are becoming some of the attractions for international and national tourists. Similarly, the caste groups such as Brahmin, Chhetri, Newar, Rai, Limbu, Tamang, Dalits living around this municipality are following Hindu, Buddhists and Christian rreligious traditions. For the livelihood purpose, most (32.22\%) of them are operating some kind of business, 29.85 percent are involving in agriculture based occupation, 17.40 percent are engaged in public and private services and remaining 20.53 percent are in other occupation such as remittance, wage labor (VM, 2018). There are total 103 institutions (government and non-government) in this municipality that includes 15 government offices, 23 banks, 50 community and private schools and colleges, 15 local and national levels I/NGOs (VM, 2018). Women from this municipality are involving in diversified occupations for supporting their family life and livelihoods. More specifically, they are joining government and non government jobs, operating local shops and agro-based enterprises and also sending remittance. However, the trend of involving in government and non-government jobs have been increasing due to the outcomes of women empowerment programs, family supports as well as internal and external motivational factors of women employment.

\section{Results: Social Demography of the Respondents}

The variables such as respondents' category, home address, age, religion, caste, marital status, education, job of respondents' husband, capacity/skill development training, land holding and primary sources of family income are briefly described in this section. In the case of respondents' category, out of 72 respondents, $44(61.11 \%)$ are belong to government institution and remaining $28(38.89 \%)$ are working in non-government institutions. In terms of home address, majorities $(55.56 \%)$ of the respondents are belonging to out of home district (i.e. Baglung, Lamjung, Syangja, Parbat, Kaski, Chitwan, Naalparasi \& Kathmandu) whereas 44.44 percent of them are from home district Tanahu. In terms of age group, out of total, most (41.67\%) respondents' age group falls between 18-25 years whereas least respondents' age group falls between age group 41-45 and 46-50 years. The median age of the respondents is 29 years.

Similarly, in the case of religion, most 44 respondents $(61.11 \%)$ are belonging to Hindu whereas Buddhists are 16 (22.22\%), and Christians are 12 (16.67\%). In the case of caste group, most $28(38.89 \%)$ respondents are belonging to Brahmin whereas least $8(11.11 \%)$ respondents are belonging to Dalit. Accordingly, 16 (22.22\%) respondents are belonging to Newar, Magar and Gurung (Janjati ethnics) and $17(23.69 \%)$ respondents are belonging to Chhetri. Regarding marital status, majority (63.90\%) of the respondents are married whereas 28.77 percent are unmarried and remaining 8.33 percent are others (i.e. divorced and widowed). In the case of educational status, majorities (52.78\%) respondents completed higher education in which 36.84 percent of them are form Management, 28.95 percent from Education, 23.68 percent from Arts, 7.89 percent from Health and 2.63 percent from Agriculture streams. Accordingly, 38.89 respondents completed secondary education, 2.77 percent studied lower secondary level and 5.56 percent found illiterate. Regarding educational status of their husband, majorities (58.34\%) are literate, 5.55 percent studied primary education, 8.33 percent studied lower secondary, and 23.61 percent completed secondary education whereas 4.17 percent are illiterate. 
Likewise, in the case of profession of respondents' husband, most $(30.56 \%)$ of them are involved in private job whereas 23.61 percent are involved in government job. Accordingly, data shows that 9.72 percent are operating shops, 12.50 percent enterprises at the same time 18.05 percent are involving in foreign employment and 5.56 percent in politics/social work. In the terms of capacity/skill development trainings, most (31.94\%) respondents objected that they did get a chance to participate in such trainings. However, 29.17 percent respondents completed computer related training, 20.83 percent completed training for preparing public service commission exam, 13.89 percent participated in health related trainings and least (4.17\%) completed financial management trainings. Regarding land holding status, most (36.11\%) have less than 10 Ropani land and least 5.55 percent respondents have more than 25 Ropani land. Accordingly, 26.39 percent respondents have 10-15 Ropani, 23.61 percent have 15-19 Ropani and 8.33 percent have 20-25 Ropani of land. Finally, in the case of primary sources of family income, most (26.38\%) respondents' found government job and least (4.17\%) found daily wages. Accordingly, 22.22 percent respondents' found private jobs, 19.44 percent found local business/ shops, 18.06 percent found remittance and 9.72 percent found agro-based entrepreneurship.

\section{Motivational Factors for Women Employment}

This section highlights on different motivational factors that is encouraging women to play gender role in the community and society and also encouraging them to develop their professional careers. Out of 72 respondents, most 48 (66.67\%) respondents are motivated by internal/external factors whereas 19 (26.39\%) motivated by internal factors and 5 (6.94\%) by external factors only. The perceptions of the respondents on research issues related to motivational factors are tried to measure through five point likert scales such as strongly agree, agree, neutral, disagree and strongly disagree (Table $2 \& 3$ ).

\section{Table 2. Motivational Outputs Related Issues}

\begin{tabular}{lccccc}
\hline Issues & $\begin{array}{c}\text { Strongly } \\
\text { Agree }\end{array}$ & Agree & Neutral & Disagree & $\begin{array}{c}\text { Strongly } \\
\text { Disagree }\end{array}$ \\
$\begin{array}{l}\text { 1.Number of job offer has been } \\
11\end{array}$ & 44 & 17 & - & - \\
increased & $(15 \%)$ & $(61 \%)$ & $(24 \%)$ & & \\
2.Recognition by coworker to me has & 9 & 48 & 13 & 2 & - \\
been increased & $(1.29 \%)$ & $(67 \%)$ & $(18 \%)$ & $(3 \%)$ & - \\
3.Capacity to specialization on my job & 15 & 49 & 7 & 1 & - \\
is increased & $(20.83 \%)$ & $(68 \%)$ & $(10 \%)$ & $(1.39 \%)$ & - \\
4.I can work on lean better than before & 15 & 50 & 4 & 3 & - \\
& $(20.83 \%)$ & $(69 \%)$ & $(5.55 \%)$ & $(4.17 \%)$ & - \\
5.I can communicate better than & 13 & 51 & 6 & 2 & - \\
before & $(18 \%)$ & $(71 \%)$ & $(8.33 \%)$ & $(2.78 \%)$ & - \\
6.My attitude towards women & 12 & 46 & 14 & - & - \\
employment is positively changed & $(16.67 \%)$ & $(64 \%)$ & $(19 \%)$ & & \\
\hline
\end{tabular}

The table 2 shows that most of the respondents' responses on all the six issues falls under agreed scale and least on disagree scale. Very interestingly, nobody response on strongly disagree scale. 
These constructive responses indicate that motivational factors are positively contributing to women employment. These empirical findings also support to Zimmerman and Schunk (2012) who claimed that outputs of motivational factors can be observed differently from one person to another. This means, the same factor cannot motivate to all that is why better to find effective factors possibly in individual basis.

Table 3. Motivational Outcomes Related Issues

\begin{tabular}{|c|c|c|c|c|c|}
\hline Issues & $\begin{array}{l}\text { Strongly } \\
\text { Agree }\end{array}$ & Agree & Neutral & Disagree & $\begin{array}{l}\text { Strongly } \\
\text { Disagree }\end{array}$ \\
\hline $\begin{array}{l}\text { 1.Number of job offer has been } \\
\text { increased }\end{array}$ & $\begin{array}{c}39 \\
(54.17 \%)\end{array}$ & $\begin{array}{c}5 \\
(6.94 \%)\end{array}$ & $\begin{array}{c}14 \\
(19.44 \%)\end{array}$ & $\begin{array}{c}8 \\
(11.12 \%)\end{array}$ & $\begin{array}{c}6 \\
(8.33 \%)\end{array}$ \\
\hline 2. Social prestige has been increased & $\begin{array}{c}30 \\
(41.67 \%)\end{array}$ & $\begin{array}{c}26 \\
(36.11 \%)\end{array}$ & $\begin{array}{c}3 \\
(4.17 \%)\end{array}$ & $\begin{array}{c}13 \\
(18.06 \%)\end{array}$ & - \\
\hline $\begin{array}{l}\text { 3.Purchasing power for consumable } \\
\text { has been increased }\end{array}$ & $\begin{array}{c}15 \\
(20.83 \%)\end{array}$ & $\begin{array}{c}39 \\
(54.17 \%)\end{array}$ & - & $\begin{array}{c}18 \\
(25 \%)\end{array}$ & - \\
\hline $\begin{array}{l}\text { 4. Their family's useless and better } \\
\text { health care has been increased }\end{array}$ & $\begin{array}{c}9 \\
(12.50 \%)\end{array}$ & $\begin{array}{c}33 \\
(45.83 \%)\end{array}$ & - & $\begin{array}{c}30 \\
(41.677 \%)\end{array}$ & - \\
\hline $\begin{array}{l}\text { 5.Their children or belonging have } \\
\text { increased access to education }\end{array}$ & $\begin{array}{c}3 \\
(4.17 \%)\end{array}$ & $\begin{array}{c}36 \\
(50 \%)\end{array}$ & $\begin{array}{c}13 \\
(18.06 \%)\end{array}$ & $\begin{array}{c}20 \\
(27.78 \%)\end{array}$ & - \\
\hline $\begin{array}{l}\text { 6.Able to buy the fixed assets/land } \\
\text { or house or vehicle or cattle (most } \\
\text { vehicles \& cattle) }\end{array}$ & $\begin{array}{c}3 \\
(4.17 \%)\end{array}$ & $\begin{array}{c}22 \\
(30.56 \%)\end{array}$ & $\begin{array}{c}25 \\
(34.72 \%)\end{array}$ & $\begin{array}{c}22 \\
(30.56 \%)\end{array}$ & - \\
\hline
\end{tabular}

(Field Survey, 2018)

The table 3 also shows that most of the respondents' responses on all the six issues falls under agreed scale and least on disagree scale. Very interestingly, only 6 respondents expressed strongly disagree on the statement "number of job offer has been increased". All these constructive responses indicate that motivational factors are also contributing to rural development in general and women empowerment in particular. In the reference of neo-Marxist feminist, the motivated women employee are becoming empowered and have been playing social, economic and political role in the society that is called gender role from rural development perspective.

\section{De-motivational Factors for Women Employment}

This section highlights on de-motivational factors that is discouraging women for developing their professional careers. Even intrinsically motivated women are also facing harassment problems with such factors. The perceptions of the respondents on research issues related to de-motivational factors are also tried to measure through five point likert scales such as strongly agree, agree, neutral, disagree and strongly disagree (Table 4). 
Table 4. De-motivational Factors Related Issues

\begin{tabular}{lccccc}
\hline Issues & $\begin{array}{l}\text { Strongly } \\
\text { Agree }\end{array}$ & Agree & Neutral & Disagree & $\begin{array}{l}\text { Strongly } \\
\text { Disagree }\end{array}$ \\
1.Unable to receive attractive salary & 6 & 27 & 15 & 22 & 2 \\
& $(8.33 \%)$ & $(37.50 \%)$ & $(20.83 \%)$ & $(30.56 \%)$ & $(2.78 \%)$ \\
2.Compelled to receive minimum & - & 20 & 24 & 28 & - \\
salary than those of male & & $(27.78 \%)$ & $(33.33 \%)$ & $(38.89 \%)$ & \\
3.Facing work pressures and burden in & 4 & 35 & 20 & 13 & - \\
office time & $(5.56 \%)$ & $(48.61 \%)$ & $(27.78 \%)$ & $(18.06 \%)$ & \\
4.Facing job insecurity & 3 & 18 & 12 & 37 & 2 \\
& $(4.17 \%)$ & $(25 \%)$ & $(16.67 \%)$ & $(51.39 \%)$ & $(2.78 \%)$ \\
5.Unable to participate in capacity/skill & 5 & 30 & 10 & 24 & 3 \\
development training & $(6.94 \%)$ & $(41.67 \%)$ & $(13.89 \%)$ & $(33.33 \%)$ & $(4.17 \%)$ \\
6.facing sexual harassment from male & 3 & 22 & 19 & 28 & - \\
employees & $(4.17 \%)$ & $(30.56 \%)$ & $(26.39 \%)$ & $(38.89 \%)$ & \\
\hline
\end{tabular}

The table 4 also shows that most of the respondents' responses on all the six issues falls under agreed scale and least on strongly disagree scale. All these constructive responses indicate that employed women are also facing de-motivational factors in the study area. This might be reason unemployment rate for the female (13.1\%) is still 2.8 percent higher than male (CBS, 2019). Thus, it is almost necessary to address such de-motivational factors of women employment for improving gender development index (0.925) of this country. The local development stakeholders including aged personsmust rethink on deeply rooted patriarchal systems of Hindu culture that is becoming demotivational factors for women employment in Nepal.

\section{Theorization and Meaning Making}

Without theoretical understanding of how society works making critical reflection on socio-cultural might be superficial (Turner, 2005, p. 4). Thus, this study tried to theorize research issues from the view points of WID, WAD and GAD Approach; Maslow's hierarchy of need and two factor theory of motivation. Regarding the first theoretical gaze, the American liberal feminists introduced WID approach in terms of economic participation and access of women. WAD approach again realized active role of women in social and economic activities. And GAD approach advocates women to play gender role (reproductive, productive and change agent) in the society and beyond (UN, 2017). Being a member country of UN, government of Nepal also started ensuring women's' right, propositional representation of women in administrative and political sectors. As an outcome of such policies, even in Vays Municipality women are becoming empowered through higher educational opportunities, capacity/skill development trainings and family supports. They become motivated with such external supports and started joining jobs in government and no-government institutions and also have been playing gender role in the society. 
Similarly, women are willing to fulfill their hierarchy of needs such as psychological, safety, social and self-actualization (Maslow, 1987). For that purpose, the women working in non-government institutions are dreaming to join government jobs and preparing public service commission exam. In flip side, women working in government and non-government institutions are facing sexual harassment instead of safety need and also demoralizing by own staffs instead of social needs. Even there is no reward and punishment system for fostering esteem needs of the employee in the institutions that could help to achieve their self-actualization need. Thus, Maslow's need hierarchy is very much essential to professional development of the women working in this municipality. It is very essential for the local development stakeholders to understand the needs of the employed women as Maslow emphasizes that when the lower need satisfy the person will move to the higher-level needs.

The next theory two factor theory of motivation (i.e. hygiene factors $\&$ motivating factors) also tried to analyze positive and negative aspects of women employment in this municipality (Higgins $\&$ Kruglanski, 2000). Most of the women working in non-government institutions are not satisfied with the hygiene factors such as working condition, salary, personal life, job security, relationship with co-workers and welfare activities. However, they are satisfied with motivating factors such as job options, recognition by coworkers, job specification, working efficiency, social prestige and improved family livelihoods. Such motivational factors are helping motivating women intrinsically. However, satisfaction of the women employees is affected by the motivating factors and the dissatisfaction of women is affected by the hygiene factors.

\section{Conclusion}

This study comes to the conclusion that motivational factors plays vital role in women employment that is foundation of rural development also. Majorities of the employed women are playing gender role (social, economic \& political role) in the community and society. There is impossible to achieve the expected sustainable development of the nation without participation of women. Intrinsically and extrinsically motivated women are performing their duty and responsibility more effectively and efficiently with an honorable way. They are also achieving better self esteem, social prestige and family supports that are most essential for their professional development. Thus better to address de-motivational factors for women employment by the local development stakeholders including aged person supporting deeply rooted patriarchal systems of Hindu culture for motivating women for employment.

\section{References}

Averett, S. L., Laura M. Argys, L. M., \& Hoffman, S. D. (Eds.). (2018). The oxford handbook of women and the economy. New York: Oxford University Press.

CBS (2019). Report on the Nepal labour Force Survey 2017/18. Kathmandu: Central Bureau of Statistics.

Chapagai, S. (2017). Analysis of motivational factors of employees working in Kumari Bank Limited (Unpublished MA Thesis, Seinajoki University of Applied Sciences). Finland: School of Business and Culture Degree programme: International Business Specialization.

Chaudhary, P. K., \& Pasa, R. B. (2015). Agriculture Education for Rural Development in Nepal. Journal of Training and Development, 1, 38-45. doi: https://doi.org/10.3126/jtd.v1i0.13089 
Fischer, C., Malycha, C. P. \& Schafman, E. (2019). The influence of intrinsic motivation and synergistic extrinsic motivators on creativity and innovation. Frontiers Psychology, 10 (137), 1-15. Retrieved from https://doi.org/10.3389/fpsyg.2019.00137

Higgins, T. E., \& Kruglanski, A. W. (2000). Motivational science: social and personality perspectives. Sheridan Books-Braun-Brumfield.

Higgins, T. E., \& Kruglanski, A. W. (2000). Motivational science: social and personality perspectives. Sheridan Books-Braun-Brumfield.

Krejcie, R. V., \& Morgan, D. W. (1970 ). Determining sample size for research activities. Educational and Psychological Measurement, (30), 607-610.

Maslow, A. H. (1987). Motivation and personality (3rd ed.). New Delhi: Dorling Kindersley (India) Private Limited.

Ministry of Health (MoH). (2016). Nepal demographic and health survey 2016. Kathmandu: Government of Nepal.

Singh, K. (2009). Rural development, principle, policies and management (3rd ed.). New Delhi: Sage Publication.

Turner, J. H. (2005). The structure of sociological theory. India: Rawat Publication.

United Nations (UN). (2017). Role of Women in Development: WID, WAD and GAD Approaches.

Vyas Municipality (VM). (2018). Profile of Vyas municipality. Author.

Yazan, B. (2015). Three approaches to case study methods in education: Yin, Merriam, and Stake. The Qualitative Report, 20(2), 134-152.

Yin, R. K. (2013). Case study research: Design and method (4th ed.). Thousand Oaks, CA: Sage Publication.

Zimmerman, B. J., \& Schunk, D. H. (Eds). (2012). Motivation and self-regulated learning: Theory, research, and applications. New York: Taylor and Francis Group. 